\title{
Pengaruh Penerapan Model Rotating Trio Exchange (RTE) Berbantuan Media Couple Card terhadap Kompetensi Belajar Peserta Didik
}

\author{
Nurul Oktaviani ${ }^{1}$,Rahmadhani Fitri ${ }^{2}$ \\ ${ }^{1,2)}$ Biology Department, FMIPA, Universitas Negeri Padang,Padang, Indonesia \\ Pengiriman: Maret 2020; Diterima: Juli 2020; Publikasi: Juli 2020
}

\begin{abstract}
UNP Laboratory Development High School has implemented the 2013 Curriculum, but it is still not optimal. The problem found is that the learning process still often teacher centered which turned students passive. In addition, teachers also do not variation the learning model. The impact is the low student learning competency. This study aims to look at the effect of the application of Rotating Trio Exchange (RTE) by the Couple Card Media on the Learning Competence of Students in Circulation System Material in the UNP Laboratory Development High School. This research is an experimental study with a Randomized Control Group Only Design research design. The population in this study were all students of class XI in the UNP Laboratory Development High School, totaling 54 students distributed in 2 classes. Sampling is done using total sampling techniques. The research instrument used form of posttest questions for aspects of knowledge, observation sheets for aspects of attitude and portfolio assessment for aspects of skills. The data analysis technique used is the $t$ test, which is first performed prerequisite tests, namely the normality test and homogeneity test. The results showed knowledge competence (77.93), attitude competence (82.00), and skills (83.89) in the experimental class were higher than the control class 68.30 respectively; 70.58; and 79.2. These results indicate that the hypothesis is accepted. Therefore, it can be concluded that the Rotating Trio Exchange (RTE) type of cooperative learning model assisted by a couple card media has a significant positive effect on the students' learning competency biology at SMA UNP Laboratory.
\end{abstract}

Kyword: Rotating Trio Exchange (RTE); Learning Competencies.

ABSTRAK. SMA Pembangunan Laboratorium UNP sudah menerapkan Kurikulum 2013, namun masih belum optimal. Permasalahan yang ditemukan adalah proses pembelajaran masih teacher centered sehingga membuat peserta didik pasif. Selain itu, kurangnya variasi model pembelajaran. Dampaknya adalah rendahnya kompetensi belajar peserta didik. Penelitian ini bertujuan untuk melihat pengaruh penerapan model Rotating Trio Exchange (RTE) Berbantuan Media Couple Card terhadap Kompetensi Belajar Biologi Peserta Didik di SMA Pembangunan Laboratorium UNP. Penelitian yang dilakukan merupakan penelitian eksperimen dengan rancangan penelitian Randomized Control Group Only Design. Populasi dalam penelitian mencakup seluruh peserta didik kelas XI di SMA Pembangunan Laboratorium UNP yang terdaftar pada tahun ajaran 2019/2020 berjumlah 54 orang peserta didik yang terdiri dari 2 kelas. Pengambilan sampel dilakukan dengan menggunakan teknik total sampling. Instrumen penelitian untuk aspek pengetahuan berupa soal posttest, untuk aspek sikap berupa lembar observasi dan untuk aspek keterampilan berupa penilaian portofolio. Teknik analisis data yang digunakan yaitu uji normalitas dan uji homogenitas sebagai uji prasyarat lalu dilakukan uji t. Hasil penelitian menunjukkan kompetensi pengetahuan (77,93), kompetensi sikap $(82,00)$, dan keterampilan $(83,89)$ pada kelas eksperimen lebih tinggi dari pada kelas kontrol berturutturut 68,$30 ; 70,58$; dan 79,22. Hasil analisis hipotesis di ketahui bahwa $t_{\text {hitung }}$ pada ketiga kompetensi ini lebih besar dari $t_{\text {tabel. }}$. Hasil ini menunjukkan bahwa hipotesis diterima. Oleh karena itu, dapat disimpulkan model $R T E$ berbantuan media couple card berpengaruh positif yang berarti terhadap kompetensi belajar biologi peserta didik di SMA Pembangunan Laboratorium UNP.

Kata kunci: Rotating Trio Exchange (RTE); Kompetensi Belajar.

*Penulis Korespondensi:

Alamat surel: nurulocha1997@gmail.com 


\section{PENDAHULUAN}

Perubahan Kurikulum Tingkat Satuan Pendidikan (KTSP) menjadi Kurikulum 2013 diharapkan dapat mewujudkan tujuan pendidikan nasional. Kurikulum 2013 dirancang untuk menghasilkan lulusan yang sesuai dengan abad 21 sehingga mampu bersaing secara global. Elemen utama dalam Kurikulum 2013 yaitu adanya perbaikan dalam kompetensi yang mencakup kompetensi pengetahuan, sikap dan keterampilan, serta perbaikan dalam kesesuaian dan kedalaman materi, proses pembelajaran, dan penilaian (Kemendikbud, 2014: 13).

Perubahan kurikulum juga diharapkan dapat memberi kesempatan kepada peserta didik untuk mengembangkan potensi yang dimilikinya. Potensi yang harus dimiliki terkait dengan kompetensi pengetahuan, sikap, dan keterampilan. Potensi yang ada dalam diri peserta didik kurang dapat terlihat ketika proses pembelajaran masih teacher center. Sesuai tuntutan Kurikulum 2013, dimana peserta didik harus menjadi pusat dalam pembelajaran maka pembelajaran harus berubah dari teacher center menjadi student center (Trianto, 2008: 7).

Pelaksanaan Kurikulum 2013 di SMA Pembangunan Laboratorium Universitas Negeri Padang baru diterapkan pada tahun 2018 sehingga pelaksanaannya masih belum optimal. Hasil wawancara dengan Guru Biologi kelas XI, Ibu Dean Roslaini, S.Pd, MM pada tanggal 31 Agustus 2019, guru sudah menerapkan model pembelajaran dalam proses pembelajaran. Model yang sering digunakan oleh guru yaitu Direct Intruction, Discovery Learning dan Problem Based Learning.
Pemilihan model pembelajaran tersebut dianggap lebih sesuai dengan semua materi biologi.

Observasi yang peneliti lakukan selama Pendidikan Kuliah Lapangan (PLK) di SMA Pembangunan Laboratorium UNP diketahui bahwa Ibu Dean sering menggunakan metode ceramah, dan tanya jawab sedangkan untuk diskusi jarang digunakan. Misalnya dalam satu pokok bahasan yang terdiri dari lima kali pertemuan, diskusi hanya dilakukan satu atau dua kali pertemuan saja. Berdasarkan hasil wawancara kepada peserta didik, mereka merasa senang saat guru menerapkan metode diskusi namun kendalanya adalah mereka menjadi kurang paham terhadap materi karena anggota kelompoknya tidak melaksanakan diskusi dengan baik. Jumlah anggota kelompok yang biasanya terdiri dari 5-6 orang menyebabkan diskusi yang dilakukan menjadi tidak efektif.

Masalah lain yang dihadapi guru yaitu kurangnya motivasi belajar. Peserta didik merasa kesulitan dalam memahami materi karena materi biologi bersifat hafalan dan dalam jumlah banyak sehingga menjadi tidak tertarik dan bosan untuk belajar. Berdasarkan hasil wawancara dengan guru biologi bahwa banyak peserta didik yang merasa sulit dalam belajar biologi karena jumlah materi yang banyak serta banyaknya proses-proses dalam materi biologi. Salah satunya yaitu materi sistem sirkulasi yang merupakan KD 3.4 di Kelas XI.

Masalah yang disampaikan sebelumnya menjadi salah satu faktor belum tercapainya kompetensi belajar pada aspek pengetahuan dengan KKM 78 yang dapat diketahui dari hasil observasi peneliti pada peserta didik kelas XI MIA 
di SMA Pembangunan Laboratorium UNP seperti pada Tabel 1.

Tabel 1.Rata-rata nilai Ujian Tengah Semester 1 Mata Pelajaran Biologi Kelas XI MIA di SMA Pembangunan Laboratorium UNP Tahun Pelajaran 2019/2020

\begin{tabular}{ccccc}
\hline Kelas & $\begin{array}{c}\text { Rata-rata } \\
\text { UTS }\end{array}$ & $\begin{array}{c}\text { Tuntas } \\
(\geq 78)\end{array}$ & $\begin{array}{c}\text { Tidak } \\
\text { Tuntas } \\
(<78)\end{array}$ & $\begin{array}{c}\text { Jumlah } \\
\text { Deserta }\end{array}$ \\
\hline $\begin{array}{c}\text { XI MIA } \\
1\end{array}$ & 55,65 & 0 & 0 & 27 \\
\hline XI MIA & 59,78 & 0 & 0 & 27
\end{tabular}

2

Sumber: Guru Biologi Kelas XI SMA Pembangunan Laboratorium UNP.

Faktor lain yang menyebabkan kurangnya motivasi dan rendahnya nilai peserta didik juga dikarenakan dalam proses pembelajaran hanya beberapa yang aktif bertanya. Hal ini karena kurangnya variasi strategi pembelajaran. Metode ceramah dan diskusi yang digunakan guru sudah baik, namun akan lebih baik jika guru memvariasikan strategi pembelajaran dikelas. Variasi ini dapat berupa variasi model dan media pembelajaran. Untuk itu, guru harus memilih model yang dapat membuat peserta didik aktif dan senang dalam untuk belajar. Salafudin dan Sudarsono (2019: 94) dalam penelitiannya mengungkapkan bahwa model RTE dapat meningkatkan aktivitas belajar peserta didik.

Observasi yang peneliti lakukan selama PLK di SMA Pembangunan Laboratorium UNP diketahui bahwa aspek keterampilan yang diamati masih tergolong rendah. Peserta didik dalam mengikuti kegiatan praktikum masih banyak yang belum mengikuti langkah-langkah kegiatan praktikum dengan benar. Selain itu, penggunakan alat praktikum masih di luar fungsi seharusnya.
Hal ini mengakibatkan kegiatan praktikum tidak kondusif. Selain itu, permasalahan yang terlihat adalah kurangnya keterampilan peserta didik dalam unjuk kerja baik berupa tindakan maupun hasil kerja berupa tugas praktik, proyek, produk, dan lain sebagainya.

Materi sistem peredaran darah merupakan salah satu pokok bahasan yang akan peserta didik pelajari di kelas XI. Materi ini memiliki cakupan yang luas sehingga membutuhkan mdel pembelajaran yang dapat membuat peserta didik termotivasi untuk belajar dan dapat memahami materi dengan baik. Salah satu model pembelajaran yang dapat memotivasi dan membuat peserta didik aktif adalah model Rotating Trio Exchange (RTE). Menurut Silberman (2006: 85) bahwa model ini merupakan salah satu model pembelajaran yang efektif bagi peserta didik untuk berdiskusi tentang berbagai masalah pembelajaran dengan beberapa anak di dalam kelas. Hasanah, dkk. (2019: 120) menyatakan bahwa pembelajaran dengan menggunakan model ini dapat menumbuhkan minat belajar. Selain agar peserta didik termotivasi untuk belajar karena menggunakan model yang menarik, peserta didik juga dapat mengembangkan kemampuan komunikasi dan dapat juga meningkatkan sikap sosialnya.

Hasil wawancara peneliti dengan peserta didik menjelaskan bahwa peserta didik lebih senang melakukan kegiatan diskusi beranggotakan 3 orang. Jika jumlah anggota kelompok terlalu banyak maka anggota kelompok lebih banyak yang bercerita. Untuk itu, model RTE mampu menjadi inovasi untuk diterapkan dalam pembelajaran karena masing-masing kelompok hanya terdiri dari 
3 orang sehingga diskusi diharapkan bisa lebih efektif. Muawanah (2019: 16) mengungkapkan model ini merupakan cara untuk berdiskusi dengan beranggotan 3 orang. Model ini diharapkan dapat melatih peserta didik untuk dapat berkomunikasi dengan baik, sehingga peserta didik saling bertukar pikiran dengan temannya dengan cara berganti pasangan dalam kelompok.

Model RTE menuntut peserta didik untuk berpindah atau berotasi dari satu kelompok ke kelompok lain, sehingga setiap pokok bahasan diskusi akan dibahas dengan kelompok yang berbeda. Variasi tersebut diharapkan dapat mengurangi kebosanan peserta didik saat diskusi sehingga pembelajaran akan lebih menyenangkan. Model ini diharapkan dapat meningkatkan kemampuan komunikasi antar peserta didik. Astuti, dkk. (2015: 6) menyatakan bahwa model ini dapat membuat peserta didik bekerjasama sehingga peserta didik aktif untuk berdiskusi. Aktivitas yang terjadi akan membuat proses diskusi menyenangkan.

Penerapan model RTE diharapkan dapat meningkatkan kompetensi belajar peserta didik. Penelitian Hasanah dan Ahmad Fathoni (2019: 5) menunjukkan bahwa penerapan model ini dapat mempengaruhi hasil belajar. Dipayana (2014: 8) menyatakan kelebihan model RTE yaitu, (1) dapat bekerjasama dan memiliki kesempatan untuk lebih dapat mengolah informasi, dan (2) membuat peserta didik aktif dan saling membantu dalam memahami materi.

Model pembelajaran akan berjalan efektif jika dibantu dengan media pembelajaran. Sudirman (2006: 7) menjelaskan bahwa media adalah sesuatu yang dapat digunakan untuk menyampaikan pesan yang dapat merangsang peserta didik untuk belajar. Salah satu media yang dapat digunakan adalah media couple card. Menurut Puspitasari (2019: 4) couple card merupakan kartu yang berisi pertanyaan dan jawaban lalu dicocokkan sesuai kartu pertanyaan.

Hasil wawancara peneliti dengan peserta didik bahwa guru biasanya memberikan Lembar Kerja Peserta Didik (LKPD) sebagai media pembelajaran. LKPD menyajikan pokok bahasan diskusi secara keseluruhan. Hal ini membuat peserta didik merasa malas untuk berdiskusi. Untuk itu, media couple card dapat digunakan sebagai pengganti LKPD dimana di dalam media couple card pertanyaan diskusi disajikan satu persatu, peserta didik akan fokus pada satu pertanyaan diskusi sehingga peserta didik akan memahami materi. Selain itu, couple card yang menarik dapat memotivasi peserta didik. Penelitian Prasetya (2013: 101) mengungkapkan bahwa penggunaan media couple card dapat membuat peserta didik mengalami peningkatan motivasi dan antusias dalam belajar.

Penerapan model RTE dengan bantuan couple card dapat meningkatkan kompetensi belajar peserta didik. Rahmi (2018: 83) menerapkan pada mata pelajaran kimia dimana menunjukkan hasil yang baik. Heliyandari (2018: 35) juga telah menerapan model ini terhadap keterampilan kooperatif dan hasil belajar peserta didik. Penelitian ini menunjukkan bahwa terdapat peningkatan kompetensi belajar peserta didik.

Berdasarkan uraian diatas, peneliti melakukan penelitian mengenai pengaruh penerapan model Rotating Trio Exchange (RTE) berbantuan media couple card terhadap 
kompetensi belajar biologi peserta didik di SMA Pembagunan Laboratorium UNP.

\section{METODE PENELITIAN}

Jenis penelitian yaitu penelitian eksperimen. Rancangan penelitian yang digunakan pada adalah Randomized Control Group Posttest Only Design. Populasi dalam penelitian adalah seluruh peserta didik kelas XI MIA di SMA Pembangunan Laboratorium UNP yang terdaftar pada tahun pelajaran 2019/2020. Jumlah anggota populasi adalah 54 orang yang terdistribusi dalam 2 kelas yaitu XI MIA 1 dan XI MIA 2.Pengambilan sampel dilakukan dengan teknik total sampling.

Instrumen yang digunakan pengumpulan data yaitu untuk tes tertulis (test) untuk kompetensi pengetahuan dan pengamatan (non test) untuk kompetensi sikap dan kompetensi keterampilan. Sebelum data dianalisis dilakukan uji prasyarat terlebih dahulu yaitu uji normalitas dan uji homogenitas.

Berdasarkan hasil uji normalitas dan uji homogenitas terhadap nilai aspek pengetahuan, sikap dan keterampilan menunjukkan data terdistribusi normal dan memiliki varians yang homogen, maka untuk uji hipotesis peneliti menggunakan uji t dengan rumus berikut.

$$
\mathrm{t}=\frac{x i-\bar{x}}{S \sqrt{\frac{1}{n_{1}}+\frac{1}{n_{2}}}}
$$

Untuk menghitung simpangan baku, digunakan rumus berikut.

$$
\mathrm{S}^{2}=\frac{\left(n_{1}-1\right) S_{1}^{2}+\left(n_{2}-1\right) S_{1}^{2}}{n_{1}+n_{2}-2}
$$

Dengan kriteria pengujian terima hipotesis nihil $\left(\mathrm{H}_{0}\right) \quad$ jika $\mathrm{t}_{\text {hitung }}<\mathrm{t}_{\text {tabel }}$ dan hipotesis kerja $\left(\mathrm{H}_{\mathrm{I}}\right)$ diterima jika $t_{\text {hitung }}>t_{\text {tabel }}$ (Sudjana, 2005: 239).

\section{HASIL DAN PEMBAHASAN}

\section{Hasil Penelitian}

Hasil penelitian kedua kelas sampel di SMA Pembangunan Laboratorium UNP, diperoleh data tentang kompetensi belajar pada aspek pengetahuan, sikap dan keterampilan. Kompetensi belajar peserta didik pada aspek pengetahuan diperoleh dari hasil tes akhir (posttest) peserta didik, pada aspek sikap dinilai setiap kali pertemuan oleh dua orang observer, sedangkan kompetensi keterampilan diperoleh dari unjuk kerja portofolio. Perhitungan rata-rata nilai, varians, dan simpangan baku kedua kelas sampel dapat dilihat pada Tabel 2 di bawah ini.

Tabel 2. Perhitungan Nilai Rata-rata, Varians, dan Standar Deviasi Kelas Sampel

\begin{tabular}{lllcll}
\hline \multirow{2}{*}{ Kompetensi } & $\begin{array}{l}\text { Kelas } \\
\text { Sampel }\end{array}$ & $\mathrm{N}$ & $\overline{\mathrm{x}}$ & $\mathrm{S}$ & \multicolumn{2}{c}{$\mathrm{S}^{2}$} \\
\hline \multirow{2}{*}{ Pengetahuan } & Eksperimen & 27 & 77,93 & 11,81 & 139,53 \\
\cline { 2 - 6 } & Kontrol & 27 & 68,30 & 12,10 & 146,37 \\
\hline \multirow{2}{*}{ Sikap } & Eksperimen & 27 & 82,00 & 4,08 & 16,65 \\
\cline { 2 - 6 } & Kontrol & 27 & 70,58 & 6,23 & 38,81 \\
\hline \multirow{2}{*}{ Keterampilan } & Eksperimen & 26 & 83,89 & 8,41 & 70,72 \\
\cline { 2 - 6 } & Kontrol & 32 & 79,22 & 8,11 & 65,72 \\
\hline
\end{tabular}

Berdasarkan Tabel 2, dapat dilihat bahwa kelas eksperimen memiliki nilai rata-rata yang lebih tinggi dibanding kelas kontrol. Hal ini karena pada kelas eksperimen menerapkan model RTE berbantuan media couple card sedangkan pada kelas kontrol menerapkan model Direct Intruction (DI). Hasil uji normalitas diperoleh harga $\mathrm{L}_{0}$ dan $\mathrm{L}_{\text {tabel }}$ pada taraf nyata 0,05 dapat dilihat pada Tabel 3.

Tabel 3. Uji Normalitas pada Kelas Sampel

\begin{tabular}{rlrrrr}
\hline Kompetensi & Kelas Sampel & $\mathrm{N}$ & $\mathrm{L}_{0}$ & $\mathrm{~L}_{\text {tabel }}$ & Ket \\
\hline \multirow{2}{*}{ Pengetahuan } & Eksperimen & 27 & 0,10 & 0,173 & Normal \\
\cline { 2 - 6 } & Kontrol & 27 & 0,16 & 0,173 & Normal \\
\hline
\end{tabular}




\begin{tabular}{llllll}
\multirow{3}{*}{ Sikap } & Eksperimen & 27 & 0,13 & 0,173 & Normal \\
\cline { 2 - 6 } & Kontrol & 27 & 0,10 & 0,173 & Normal \\
\hline \multirow{2}{*}{ Keterampilan } & Eksperimen & 27 & 0,11 & 0,173 & Normal \\
\cline { 2 - 6 } & Kontrol & 27 & 0,16 & 0,173 & \multirow{2}{*}{ Normal } \\
\hline
\end{tabular}

Berdasarkan Tabel 3, diketahui bahwa kompetensi belajar peserta didik kedua kelas sampel terdistribusi normal. Setelah dilakukan uji normalitas maka dilakukan uji homogenitas untuk mengetahui apakah data memiliki varians yang homogen atau tidak. Hasil uji homogenitas dapat dilihat pada Tabel 4 .

Tabel 4. Hasil Uji Homogenitas pada Kelas Sampel

\begin{tabular}{|c|c|c|c|c|c|}
\hline Kompetensi & $\begin{array}{c}\text { Kelas } \\
\text { Sampel }\end{array}$ & $\alpha$ & $\mathrm{F}_{\text {hitung }}$ & $\mathrm{F}_{\text {tabel }}$ & Keterangan \\
\hline \multirow[b]{2}{*}{ Pengetahuan } & Eksperimen & \multirow{6}{*}{0,05} & \multirow{2}{*}{0,95} & \multirow{6}{*}{1.90} & \multirow{2}{*}{ Homogen } \\
\hline & Kontrol & & & & \\
\hline \multirow{2}{*}{ Sikap } & Eksperimen & & 042 & & \multirow{2}{*}{ Homogen } \\
\hline & Kontrol & & $0,+3$ & & \\
\hline \multirow{2}{*}{ Keterampilan } & Eksperimen & & \multirow{2}{*}{1,08} & & \multirow{2}{*}{ Homogen } \\
\hline & Kontrol & & & & \\
\hline
\end{tabular}

Berdasarkan Tabel 5 diketahui bahwa $\mathrm{t}_{\text {hitung }}>\mathrm{t}_{\text {tabel }}$, maka HI diterima, yaitu penerapan model RTE berbantuan media couple card berpengaruh positif terhadap kompetensi belajar peserta didik pada aspek pengetahuan, sikap dan keterampilan di SMA Pembangunan Laboratorium UNP.

\section{Pembahasan}

\section{Pengaruh Model Rotating Trio Exchange} (RTE) Berbantuan Media Couple Card terhadap Kompetensi Belajar pada Aspek

\section{Pengetahuan}

Berdasarkan analisis data diketahui bahwa rata-rata nilai aspek pengetahuan peserta didik kelas eksperimen yang diberi perlakuan menggunakan model RTE berbantuan media couple card memiliki nilai pengetahuan yang lebih tinggi dibandingkan dengan kelas kontrol. Hasil analisis uji hipotesis diketahui memiliki pengaruh positif sehingga terjadi peningkatan kompetensi belajar pada aspek pengetahuan peserta didik di SMA Pembangunan Laboratorium UNP.

Berdasarkan hasil analisis, aspek pengetahuan di kelas eksperimen lebih baik dibandingkan kelas kontrol. Hal ini sejalan dengan penelitian Sadikin (2017: 77) dan penelitian Noviyana (2016: 69) yang menunjukkan bahwa terdapat perbedaan nilai hasil belajar peserta didik pada kelas eksperimen dengan kelas kontrol.

Kompetensi belajar pada aspek pengetahuan di kelas eksperimen mengalami peningkatan karena menerapkan model RTE berbantuan media couple card. Model ini menuntut peserta didik aktif untuk bekerjasama dalam kelompok melalui perputaran anggota kelompok yang beranggotakan 3 orang (trio). Peserta didik dapat bekerjasama dengan kelompok lain melalui perputaran sehingga mempunyai banyak kesempatan untuk mengolah informasi yang diperoleh dan mudah dalam menemukan serta memahami konsep yang sulit. Dipayana (2014: 8) menjelaskan bahwa model ini dapat membuat peserta didik aktif serta saling membantu dalam menguasai materi. Sejalan dengan itu, penelitian Satuman (2019: 42) juga menyatakan penerapan model tersebut dapat meningkatkan hasil belajar.

Media couple card yang digunakan juga dapat membuat peserta didik lebih faham materi karena soal disajikan satu persatu. Peserta didik akan mendiskusikan ssoal yang diberikan sehingga mereka akan memahami 
konsep dengan baik. Penelitian Sukmawati (2016:

4) menjelaskan bahwa penggunaan media ini di kelas eksperimen dapat membuat peserta didik faham terhadap materi.

\section{Pengaruh Model Rotating Trio Exchange} (RTE) Berbantuan Media Couple Card terhadap Kompetensi Belajar pada Aspek Sikap

Penilaian kompetensi belajar peserta didik pada aspek sikap dilakukan oleh 2 orang observer dengan menggunakan lembar observasi. Kelas eksperimen yang diberi perlakuan menggunakan model RTE berbantuan media couple card lebih baik dibandingkan dengan kelas kontrol. Hasil analisis uji hipotesis diketahui memiliki pengaruh positif sehingga terjadi peningkatan kompetensi belajar pada aspek sikap peserta didik di SMA Pembangunan Laboratorium UNP.

Pembelajaran menggunakan model RTE berbantuan media couple card membuat peserta didik berinteraksi dan bekerjasama dengan yang lain. Penelitian Wahono (2013: 57) menyatakan bahwa model ini terbukti mampu meningkatkan interaksi sosial karena membutuhkan keaktifan dan kerjasama kelompok dalam pembelajaran, serta menumbuhkan semangat saling menghargai dalam berpendapat pada menyampaikan gagasan. Penelitian Yuliyati (2016:103) juga menyatakan bahwa penerapan model ini memiliki kategori baik dilihat dari aspek kerja sama, santun, toleran, responsif dan proaktif.

Pembelajaran menggunakan model $R T E$ berbantuan media couple card dapat meningkatkan aktivitas belajar peserta didik. Sintaks pada model ini menuntut peserta didik untuk berotasi dari satu kelompok ke kelompok lainnya. Peserta didik akan mendiskusikan setiap soal yang diberikan dengan kelompok berbeda sehingga dapat melatih peserta didik untuk menghargai pendapat setiap anggota kelompok. Hal tersebut sesuai dengan penelitian Frensita (2014:50) dan Ekawati (2018:183) menyatakan penerapan model ini dapat membuat peserta didik lebih aktif. Penelitian Lagawati (2014:26) juga menjelaskan bahwa peserta didik sudah terlibat aktif dalam diskusi kelompok serta dapat bekerjasama dengan anggota kelompoknya.

Adanya variasi dalam model RTE dapat menarik perhatian sehingga peserta didik aktif dalam proses pembelajaran. Selain itu, selama proses pembelajaran peserta didik tidak akan merasa bosan karena setiap selesai mendiskusikan satu soal, kelompok akan dirotasi. Kompetensi sikap peserta didik pada kelas kontrol lebih rendah karena proses pembelajaran masih teacher centered sehingga menyebabkan peserta didik pasif. Proses pembelajaran juga membuat peserta jenuh sehingga kompetensi sikap peserta didik rendah. Penelitian Asmawati (2016: 347) menjelaskan bahwa penerapan model ini pada suatu pembelajaran dapat memberi perubahan dan memotivasi siswa untuk mengikuti pelajaran.

\section{Pengaruh Model Rotating Trio Exchange} (RTE) Berbantuan Media Couple Card terhadap Kompetensi Belajar pada Aspek

\section{Keterampilan}

Kompetensi belajar pada aspek keterampilan peserta didik dinilai melalui tugas makalah yang dikumpulkan. Hasil kompetensi belajar aspek keterampilan kelas eksperimen yang diberi perlakuan menggunakan model RTE berbantuan media couple card lebih baik. Hasil analisis uji hipotesis diketahui memiliki pengaruh positif 
sehingga terjadi peningkatan kompetensi belajar pada aspek keterampilan peserta didik di SMA Pembangunan Laboratorium UNP.

Penerapan model RTE berbantuan media couple card dapat meningkatkan kompetensi keterampilan peserta didik. Peningkatan ini disebabkan karena adanya perputaran anggota kelompok sehingga terdapat komunikasi yang baik antar peserta didik. Penelitian Heliyandri (2018: 5) menunjukkan peningkatan hasil belajar pada aspek keterampilan setelah diterapkan model RTE. Penelitian Anggraini (2015:34) juga menjelaskan bahwa terdapat peningkatan yang signifikan terhadap kompetensi keterampilan peserta didik setelah menerapkan model tersebut.

Berdasarkan uraian di atas dapat disimpulkan bahwa model RTE berbantuan media couple card berpengaruh positif terhadap peningkatan kompetensi belajar peserta didik pada aspek pengetahuan, sikap dan keterampilan di SMA Pembangunan Laboratorium UNP.

\section{KESIMPULAN}

Berdasarkan penelitian yang telah dilakukan, diketahui bahwa kompetensi belajar peserta didik kelas eksperimen lebh tinggi dibandingkan kelas kontrol. Oleh karena itu, disimpulkan bahwa model RTE berbantuan media couple card memiliki pengaruh positif terhadap peningkatan kompetensi belajar biologi peserta didik kelas XI MIA di SMA Pembangunan Laboratorium UNP.

\section{DAFTAR PUSTAKA}

Amaliah, Rezeki. 2017. Hasil Belajar Biologi Materi Sistem Gerak dengan Menerapkan Model Rotating Trio Exchange (RTE) pada Siswa Kelas
XI SMAN 4 Bantimurung. Jurnal Dinamika,Vol. 08, No.1: 11-17.

Anggraini, Hasti. 2015. Penerapan Model Pembelajaran Rotating Trio Exchange (RTE) untuk Meningkatkan Kualitas Pembelajaran Materi Upaya-upaya Penegakan HAM di Indonesia. Jurnal Forum Ilmu Sosial. Vol. 42, No. 1: 27-37.

Asma, Nur. 2009. Model Pembelajaran Kooperatif. Padang: Universitas Negeri

Padang Press.

Asmawati. 2016. Peranan Model Pembelajaran Kooperatif Tipe Rotating Trio Exchange (RTE) terhadap Hasil Belajar Fisika Peserta Didik. Jurnal Pendidikan Fisika. Vol. 4, No. 3: 343-348.

Kelas VIIB SMP Negeri 13 Makassar

Astuti, Rini. 2015. Penerapan Model Rotating Trio Exchange (RTE) untuk Meningkatkan Prestasi Belajar Siswa Pada Pokok Bahasan Hidrolisis Garam di Kelas XI IPA SMA N 9 Pekanbaru. Skripsi. Riau: Universitas Negeri Riau.

Dipayana, I Md Dyatma, I Gst. Ngr. Japa, I Md. Suarjana. 2014. Pengaruh Model Pembelajaran Rotating Trio Exchange (RTE) terhadap Hasil Belajar Matematika. Jurnal Ilmiah. Vol. 6 No. 1: 1-10.

Ekawati, Sri. 2018. Penggunaan Model Pembelajaran Kooperatif Tipe Rotating Trio Exchange untuk Meningkatkan Hasil Belajar Ekonomi pada Topik Persamaan Dasar Akutansi. Jurnal Pendidikan Tabusai. Vol. 2, No. 2: 176-184.

Frensita, Dina, Dinawati Trapsilasiwi dan Nurcholif D. S. L. 2014. Penerapan Model Rotating Trio Exchange untuk meningkatkan Hasil Belajar Peserta Didik Kelas VII A pada Sub Pokok Bahasan keliling dan Luas Bangun Segitiga dan Segiempat di SMP Negeri 1 Ajung Semester Genap Tahun Ajaran 2012/2013. Jurnal Pancaran. Vol. 3, No. 2: 43-52.

Hasanah, Mariawati dan Ahmad Fathoni. 2018. Penerapan Model Tipe Rotating Trio Exchange Berbantu Multimedia Interaktif terhadap Hasil Belajar Edumatic. Jurnal 
Pendidikan Informatika, Vol. 3, No. 1: 16.

Hasanah, Nor Fajariyatul, Mohammad Edy Nurtaman, dan Umi Hanik. 2018. Pengaruh Model Rotating Trio Exchange (RTE) terhadap Hasil Belajar dan Minat Belajar Matematika Peserta Didik Kelas V SDN Pinggir Papas 1 Sumenep. Jurnal Widyagogik, Vol. 6, No. 2: 112-121.

Hamalik, Oemar. 2009. Proses Belajar Mengajar. Jakarta: Bumi Aksara.

Heliyandari, Y. 2018. Penerapan Model Rotating Trio Exchange terhadap Keterampilan Kooperatif dan Hasil Belajar Peserta Didik pada Materi Momentum dan Impuls. Jurnal Penelitian Pembelajaran Fisika, Vol. 9, No. 1: 28-35.

Kemendikbud. 2016. Panduan Teknis Penilaian di Sekolah Dasar. Jakarta.

Lagawati, Farida Dwi. 2014. Peningkatan Minat dan Prestasi Belajar Matematika dengan Model RTE. Jurnal Derivat. Vol.1, No.1: 1928.

Muawanah, Siti Fatimatul, Zainal Abidin, Surya Sari Faradiba. 2019. Penerapan Model Pembelajaran Rotating Trio Exchange dengan Media LKPD untuk Meningkatkan Kemampuan Komunikasi Matematis Materi Perbandingan Siswa MTS Al-Amin Malang. Jurnal Pendidikan, Vol 14, No. 7: 1-7.

Neshia, Wisya, Mitri Irianti, Zuhdi Ma'ruf. 2018. Penerapaan Model Pembelajaran Rotating Trio Exchange (RTE) untuk Meningkatkan Hasil Belajar Fisika Siswa Kelas XI SMAN 14 Pekanbaru. Skripsi. Riau: Universitas Riau.

Noviyana, Hesti. 2016. Pengaruh Model Rotating Trio Exchange (RTE) terhadap Hasil Belajar Matematika Siswa Kelas VII Semester Genap SMP Negeri 17 Bandar Lampung Tahun Pelajaran 2014/2015. Jurnal Lentera. Vol. 2.

Prasetya, Diky. 2013. Implementasi Metode Think Pair Share dengan Menggunakan Media Couple Card pada Kompetensi Dasar Kenampakan Alam dan Keragaman Suku Bangsa untuk Meningkatkan Motivasi
Belajar Siswa Kelas IV SDN Sidorejo 02 Saradan Madiun. Skripsi. Malang: UIN Maulana Malik Ibrahim.

Puspitasari, Ai Nina Karlina. 2019. Penerapan Teams Games Tournament Bermedia Couple Card untuk Meningkatkan Berpikir Kritis dan Hasil Belajar Siswa. Skripsi. Bandung: Universitas Pendidikan Indonesia.

Sadikin, Ali. 2017. Pengaruh Penerapan Model Rotating Trio Exchange terhadap Hasil belajar Mata Kuliah Dasar-Dasar dan Proses Pembelajaran Biologi. Jurnal Biodik. Vol. 3, No. 2: 73-80.

Salafudin, Faisal dan Bambang Sudarsono. 2019. Peningkatan Aktivitas dan Hasil Belajar Peserta Didik dengan Model Rotating Trio Exchange di SMK Tunas Nusantara Purworejo. Jurnal Pendidikan Teknik Otomotif. Vol. 13, No. 01: 91-95.

Silberman, Melvin L. 2006. Active Learning 101 Cara Belajar Siswa Aktif. Bandung: Nusamedia

Sudjana. 2009. Metode Statistika. Bandung: Tarsito Satuman. 2019. Peningkatan Keterampilan Mempraktikkan Permainan Bola Voli pada Mata Pelajaran Penjasorkes melalui Pendekatan Model Rotating Trio Exchange siswa Kelas VI SDN Keper Kecamatan Krembung. Jurnal Revolusi Pemdidikan. Vol. II, No. 3: 36-43.

Wahono. 2013. Efektivitas Model Rotating Trio Exchange (RTE) terhadap Hasil Belajar Kompetensi Dasar Atmosfer dan Hidrosfer Kelas VII SMP 9 Semarang Tahun Ajaran 2012/2013. Skripsi. Semarang: Universitas Negeri Semarang.

Yuliyati, Baharuddin, dan Rafiqah. 2016. Penerapan Model Rotating Trio Exchange (RTE) untuk Meningkatkan Hasil Belajar Peserta Didik pada Mata Pelajaran Fisika. Jurnal Pendidikan Fisika, Vol. 4, No. 2: 1-4. 